\title{
COMMODUS RESTITUTOR COMMERCIORUM. THE ROLE OF PALMYRENE TRADING COMMUNITY AT POROLISSUM
}

\author{
Coriolan Horațiu Opreanu ${ }^{1}$
}

\begin{abstract}
The author revisits an inscription found in 1986 in the shrine of the customs station at Porolissum (Jac village, Sălaj County, Romania). His new approach offers a new meaning to the epithet restitutor commerciorum addresed to emperor Commodus in the text of the inscription: commercium has in Latin written sources and in inscriptions also the sense of the place where barbarians were trading with the Romans in the vicinity of the Roman frontiers' forts. The new interpretation is linked with the archaeological discovery at Porolissum, near the customs building of a marketplace identified by 129 coins and 43 barbarian brooches. Author's conclusion in an earlier published book is that the brooches attest, very probable, a slave market. Another valuable merchandise recovered in the excavation is raw amber of Baltic Sea coast origin, proving the existence of a branch of the Amber Road, entering in the Empire at Porolissum. The next question approached by the author concerns the merchants able to support the distribution of these valuable goods across the Empire. He proposed as main candidate the Palmyrene civilian community recorded in the inscriptions at Porolissum. Then he explains the topographical position of the Palmyrene cult complex at Porolissum. The temple of Bel, the open=air altar and the banqueting hall were situated in the near neighbourhood of the customs building just because of the Palmyrene community's economic interest. He argued his hypothesis with the example of the Palmyrene temple in Rome.
\end{abstract}

Keywords: commercium, trade, banqueting hall, Palmyrene community, temple

Between 1986 and 1988 N. Gudea excavated at Porolissum a fortlet situated at the end of the Roman imperial road where he identified the customs building. ${ }^{2}$ Outside the fortification, affixed to its Eastern wall, there was a two-rooms building facing the last segment of the imperial road. Gudea proposed here the offices of the customs' clerks, mainly the tabularium. ${ }^{3}$ Today, after the find of the construction inscription, its destination was rightly changed into the shrine of the customs. ${ }^{4}$ Inside the bigger room Gudea found two limestone honorific altars with inscriptions and other four limestone bases from lost monuments. One of them worth to be revisited (Fig. 1). Here is the text:

\author{
PRO SALVTE \\ ET VICTORIA \\ IMP(eratoris) CAES(aris) $[\mathrm{m}(\operatorname{arci})$ \\ aur(elii) antonini \\ commodi $\mathrm{p}$ (ii) fel(icis)] \\ AVG(usti) N(ostri) RESTITV
}

\footnotetext{
${ }^{1}$ Institute of Archaeology and Art History, Romanian Academy Cluj Branch, Mihail Kogălniceanu Str. 12-14, 400084, Cluj-Napoca, Cluj County, RO; e-mail: choprean@yahoo.com

2 GUDEA 1996.

3 GUDEA 1996, 35; 49.

4 PISO/OPREANU/DEAC 2015.
} 


\section{TORI(s) COMMERC(iorum) \\ ET GENIO P(ublici) P(ortorii) ILLY \\ RICI CL(audius) XENOPHON \\ PROC(urator) AVG(usti) N(ostri) PER \\ MARCION(em) ET POL(ionem) VIL (icos)}

\section{Discussion}

N. Gudea briefly mentioned that the monument belongs to the first part of Commodus reign. ${ }^{5}$ Later, I. Piso's more professional approach proposed a chronology between AD 187189. ${ }^{6}$ Commodus got the title of Pius between 10 December 182 and 3 January 183, while he became Felix after the killing of the praetorium praefectus Sextus Tigidius Perennis in April-May 185. ${ }^{7}$ We think that some additional data can be provided analyzing the meaning of the dedication "Pro salute et Victoria". It is possible that the formula is related to expeditio Germanica III, as Piso proposed. But there are some discussions on the chronology of this war. Some scholars considered this is the same with expeditio Burica ${ }^{8}$ recorded in an inscription from Regensburg? dating the war in AD $181 / 183^{10}$, or in AD $182 / 183^{11}$, while others thought that in AD 185, or even in AD 188 was a real expeditio Burica et Sarmatica. ${ }^{12}$ The mentioning of Victoria imperatoris in the inscription at Porolissum must talk to some recent event. If expeditio Germanica III dates from 181/183 and the title of Felix makes us think at a date post 185, is hard to believe (even not impossible) that the third Germanic war was three to five years later mentioned in an inscription. ${ }^{13}$ But there is another possibility: the emperor's Victory could be the so-called "bellum desertorum" 14 so, following this hypothesis ${ }^{15}$, dating of the inscription at Porolissum is after 12 August 186, the year when Commodus also celebrated his decennalia. ${ }^{16}$ It is worth adding that the literary sources talk of "victi Daci"17, possible an allusion to fights over the frontiers of the Empire. An inscription from Ampelum (Zlatna) mentions "Victoria Commodi", possible dating from AD 182-185. ${ }^{18}$ If so, Piso's chronology, may be updated to AD 185-187. Anyway, still remain more possibilities of interpretation of the dedication "”pro salute et Victoria" from the Porolissum epigraph.

The epithet "restitutor commerciorum" was unknown among Commodus titles till the inscription at Porolissum was found. N. Gudea rightly linked it with the Marcomannic wars and understood its meaning as the end of an insecure situation, without offering a precise translation. ${ }^{19}$ I. Piso read commerc(ii) instead of commerc(iorum), considering that commercia were the trading articles, but in the context of the inscription is more appropriate commercium which, in his opinion, had the meaning of trade understood as juridical transaction of

5 GUDEA 1996, 75-82.

6 PISO 2013, Nr. $94=126$

7 VAN'T DACK 1991, 334; KIENAST/ECK/HEIL 2017, 142.

8 On expeditio Burica, see also, NEMETI 2016.

9 CIL III, 5937.

10 DIETZ 1994.

11 SALDERN 2003, 82.

12 FITZ 1962; CASSOLA 1970; see, KIENAST/ECK/HEIL 2017, 140 with bibliography.

13 IDR III/3, 334.

14 ALFÖLDI 1971.

15 Rejected by SALDERN 2003, 78.

16 KIENAST/ECK/HEIL 2017, 140-141.

17 SHA, Comm., 13. 5; Cassius Dio, 72.8.1.

18 SALDERN 2003, 84.

19 GUDEA 1994, 78. 
merchandise and maybe of exchanges over the frontier. ${ }^{20}$ Piso's hypothesis is generally reasonable, but there is another possible interpretation of the inscription, closer to the ancient reality of the place. Claudia Moatti ${ }^{21}$ showed that besides the meaning of mercatura (trade), Latin commercium had also more precise meanings. In Roman law terms it offered to foreigners the legal personal, or collective right to buy and sell goods on Roman soil under the frame of diplomatic agreements. During the imperial period as part of the relations of the Empire with the barbarian tribes, by a sliding of sense, commercium became the place where this legal right was performed and where the legal exchanges have taken place. ${ }^{22}$ The spatial sense is literary attested starting with the $1^{\text {st }}$ century $\mathrm{AD}$, but mainly in the $2^{\text {nd }}$ century continuing to be recorded in the literary, epigraphic and juridical sources till the Late Roman period. Concerning the meaning of restitutor commerciorum from the inscription at Porolissum, the French scholar affirms that it is no doubt related to the trade with Barbaricum, Commodus reestablishing the function of places where barbarians were permitted to trade legally with the Romans. The Roman diplomacy used the trading right during the Marcomannic wars forbidding or allowing different barbarian people to attend Roman frontier's commercia. ${ }^{23}$ The most relevant record of such a commercium comes from a $4^{\text {th }}$ century inscription from Solva, on the Danube frontier of Pannonia. Emperor Valentinian ${ }^{24}$, following Commodus actions of consolidating the Danube frontier ${ }^{25}$, built numerous burgi on the left bank of the river. It is about an inscription from Esztergom (Hungary) dated AD 371 recording the function and name of a burgus built on the left bank of the Danube in Barbaricum: burgum cui nomen commercium qua causa et factus est. ${ }^{26}$ The main role of that burgus was obviously to shelter and supervising a market where barbarians from outside the Empire were trading with the Romans. ${ }^{27}$ A commercium across Solva was supposed to exist in the $2^{\text {nd }}-3^{\text {rd }}$ centuries $A D .^{28}$ Coming back to Porolissum, a fortunate rescue excavation offered us in 2013 the opportunity of a unique find. An area of approximately 3.500 sq. $\mathrm{m}$ situated in the very neighbourhood of the customs building, outside the wall which separated in this zone the province from Barbaricum was excavated (Fig. 2). The only archaeological structures identified were few pits, several post-holes and stick-holes (Fig. 3). It was not possible to find a definite arrangement for these structures. They were interpreted as traces of temporary wooden stalls. In contrast with the poor constructive aspect the artifacts recovered were numerous, diverse and significant. Of great interest were the 129 coins and the 43 brooches. The site was interpreted as a marketplace, where Barbarians from the settlements from vicinity of the limes were trading with the Romans. ${ }^{29}$ The use of the marketplace started very probable after the ending of the Marcomannic wars and continued till the end of the Roman rule in Dacia, two chronological stages being separated after the analysis of coins and brooches all recorded in precise archaeological contexts (Fig. 4). The marketplace identified at Porolissum was one of the commercia along the limes mentioned in the written sources. It is the first one archaeologically identified. It seems it started to function after the end of the Marcomannic wars in Commodus time, as part of some diplomatic agreements which must have existed with the barbarian people living

20 PISO 2013, 194.

${ }^{21}$ MOATTI 2011.

22 MOATTI 2011.

23 Cassius Dio 71, 11; 15.

24 ŠAŠEL KOS 1996.

25 KOVÁCS 2008.

26 RIU 771.

27 POULTER 2014, 40.

28 STOKLAS 2019, 187, Fig. 1.

29 OPREANU/LĂZĂRESCU 2015. 
in the neighbourhood of Dacia. ${ }^{30}$ The inscription from the customs building at Porolissum is possible directly related to this commercium if we take into consideration the unique record of this title of Commodus. In this case the reading would be restitutoris commerc(ii). For all that, the official character of the text, being mentioned also the procurator of the customs district of Illyricum, makes more plausible the form commerc(iorum) concerning the reopening of more commercia from the limes. Anyway, we cannot know what the ancient people were understanding while reading the abbreviation commerc. From this point of view even Piso's interpretation must not be totally rejected.

The great importance of this commercium at Porolissum is marked out by the trading of amber brought from the Baltic Sea coast ${ }^{31}$, very valuable in the Roman Empire. If the great Amber Route passed through Carnuntum on the way to Italy ${ }^{32}$, the ramification of this road entering in the Empire at Porolissum ${ }^{33}$ was of great importance for the purveyance of amber for whole Dacia and the other Balkan provinces south of the Danube.

The finding of an important number of barbarian brooches and their typological diversity was interpreted ${ }^{34}$ as the evidence for existence of a slaves' market ${ }^{35}$ in the commercium at Porolissum. If barbarians were providing the market with this valuable merchandise, who were the Roman purchasers at Porolissum able to invest and distribute it over all in the provinces? We have little information concerning the civilian population of Porolissum. Most of the votive inscriptions were dedicated by members of the municipal aristocracy. Most of the twelve persons are of oriental origin. ${ }^{36}$ Four of them are of Palmyrene birth: P. Aelius Iacubus ${ }^{37}$, P. Aelius Malachus ${ }^{38}$, Valerius Them(es?), Aurelius Gaianus. The presence of Palmyrene people is not unusual in a frontier station where among the troops in garrison was known numerus Palmyrenorum Porolissensium..$^{39}$ But most of the attested members of Porolissum municipal aristocracy are civilians, very probable merchants ${ }^{40}$, a profession very popular through the Palmyrene communities everywhere in the towns of the Roman Empire, or in the Persian Empire. Their presence at Porolissum is not at all surprisingly. Two of them, P. Aelius Malachus and P. Aelius Iacubus are known from votive altars dedicated to Iupiter Optimus Maximus ${ }^{41}$ found reused in the eastern precinct wall of the fort from Pomet Hill. After emperor Decius ${ }^{42}$ reign the defense system of the fort was so damaged that the civilian and military community at Porolissum

30 Some mentioned by Cassius Dio LXXII, 3.1.

31 OPREANU/LĂZĂRESCU 2015

32 See, TEICHNER 2013; GROH/SEDLMAYER 2019.

33 OPREANU/LĂZĂRESCU 2015.

34 OPREANU/COCIȘ/LĂZĂRESCU 2020.

35 KOLENDO 2000.

36 ARDEVAN 1998, 187-188; 566 (Tab. XXVI).

37 He was considered of Jewish origin by some authors, but his position in the social elite of the town and his citizenship from Hadrian's time when the Jews were the enemies of the Roman state make this hypothesis improbable (cf. ARDEVAN 1998, footnote 173 with bibliography).

38 Malachus is a Latinized variant of a Semitic name. Malichus I (59-30 BC), was the king of the Nabataeans recorded in an inscription in Nabataean Aramaic from 35 BC (RÍO SÁNCHEZ 2015, 82), while king Malichus II ruled between 40-70 AD (RÍO SÁNCHEZ 2015, 91). The name Malchus is known also at Aquileia, considered as the Latin transcription of the Semitic mlk very common in Palmyra. The transcription was probably from Aramaic, while from Arabic would have been Malichos, or Malechus (GRASSI 2010, 14). For the Arabic meaning of "king" for $m l k$, see (MONFERRER-SALA 2013).

39 For the history of the unit, see TENTEA 2012, 73-75.

40 ARDEVAN 1998.

41 CHIRILĂ ET ALII 1980

42 A statue base of Herennia Etruscilla from AD 251 was reused to block the porta decumana of the fort (see, DAICOVICIU 1937-1940, 328-330, 7f, Fig. 26=ILD I 672) 
sacrificed everything trying desperately to fix it. ${ }^{43}$ The eastern wall faced the forum. ${ }^{44}$ The votive inscriptions were taken as raw building material, probably from a yet unidentified Capitoline temple. But P. Aelius Malachus was not only flamen and quinquennalis of municipium Septimium Porolissense, but also sacerdos Dei Numeri Palmyrenorum Porolissensium. This god was obviously Bel. ${ }^{45}$ His name was not mentioned in the inscription due to official position of the dedicant and not to compete with the votive action addressed to Iupiter Optimus Maximus. He used a form trying to place $\mathrm{Bel}$ in an official status, as the god of a Roman auxiliary unit and not of a foreign ethnic group. Besides P. Aelius Malachus' high municipal political and religious appointments his position in Porolissum society was based, very probably, on his wealthy. As a rich civilian of Palmyrene provenience, he was very probable a merchant. ${ }^{46}$ There is not any indication that he was a former soldier. It seems that the sacerdotes of Bel at Porolissum were part of the civilian Palmyrene community. ${ }^{47}$ The temple of $\mathrm{Bel}$ was built sometimes in the $2^{\text {nd }}$ century, after the arrival of the oriental military unit in AD 120, probably in late Hadrian's-early Antoninus Pius' reign, as other stone monuments at Porolissum. ${ }^{48}$ The excavation in the temple recovered an inscription ${ }^{49}$ from Caracalla time when the temple was rebuilt after a fire by the numerus Palmyrenorum Porolissensium. In vicinity of the temple at only $0.80 \mathrm{~m}$ from its eastern corner, was excavated another rectangular building of $23 \times 13,20 \mathrm{~m}$. On its longer side it was a porticus composed of five columns with bases of $0,90 \times 0,90 \mathrm{~m}$. The room from the backside was heated with a hypocaustum installation. ${ }^{50}$ In his brief report the excavator mentioned that it was a public building used in connection with the ceremonies of the cult of $\mathrm{Bel}$, even he did not exclude the possibility to be another temple. ${ }^{51}$ The architecture of the building is not related to a temple. It was an assembly hall. From the main entrance of the temple starts a paved alley directing to an altar placed in the space between the two buildings. Only the basement of the former altar of around $2 \times 2$ m survived. ${ }^{52}$ There was a cult complex made of three elements: the temple of $\mathrm{Bel}$, the banquet hall and the open-air altar (Fig. 5). The building annexed to the temple is of great interest. Unfortunately, the archaeological finds were never published. ${ }^{53}$

Such assembly rooms for religious groups meetings are well known in Hellenistic and Roman Near East. ${ }^{54}$ In Rome, the 1859 excavation in Vigna Bonelli found a building structure used by the Palmyrene groups. ${ }^{55}$ An inscription for Deus Sol Victor put by a wines' merchant $Q$. Octavius Daphinus talks about his construction, with priests' accept: “... tricliam fec(it) a solo inpen (sa) sua permissu kalator (um) po[ntific(um)] et flaminum...". ${ }^{56}$ Another inscription in Rome mentioning more assembly halls was dedicated by C. Iulius Anicetus: “...C. Iulius Anicetus ex

43 For the general historical context, see PISO 2018.

44 For the position of the forum at Porolissum see, OPREANU/LĂZĂRESCU 2019.

45 For Bel, see GAWLIKOWSKI 2015.

46 ANDRADE forthcoming, considered Malachus was the descendant of a veteran from numerus Palmyrenorum. We thank Professor Andrade for sending his unpublished manuscript and for permission to cite it. It is possible, even in the inscription is not mentioned his position of veteranus. Valerius Theme(es?), also a decurion of the municipium is named veteranus in his inscription for Silvanus Domesticus (GUDEA 1989, 768, nr. 33).

47 Another sacerdos of Dea Syria, or Bel, being at the same time decurio municipii Porolissensium was Aurelius Gaianus (DAICOVICIU 1937-1940, 352, nr. 6).

48 TOTH 1978; OPREANU/LĂZĂRESCU 2016.

49 GHERGARIU 1980; ILD 663.

50 GUDEA ET ALII 1983, 132; TAMBA 2008, 350.

51 GUDEA ET ALII 1983, 132-133.

52 CHIRILĂ ET ALII 1980, 93-94, Fig. 4; 6.

53 TAMBA 2008, 351.

54 NIELSEN 2015.

55 TERPSTRA 2013, 152; TERPSTRA 2016.

56 CIL VI, 712. 
imperio Soli rogat ne quis velit parietes aut triclias inscribere aut scariphare" ${ }^{57}$ Triclia was the banquet hall so well known for the Palmyrene temples. In Palmyra four such cultic dining buildings are known, some of them attested by inscriptions. ${ }^{58}$ Many triclinia with the same destination are also known from Petra, Dura-Europos. ${ }^{59}$ In Palmyrene communities these halls associated with the temples were used for banquets in honour of the gods, called marzéah, a ritual meal of a group of people, a so-called "drinking society", where wine consumption was associated with meat meals and music. Marzéah was a sort of "religious guild", or a "confraternity", housed in a smk' dnh, a banqueting hall. ${ }^{60}$ The same banquets must have taken place also in the building from the very neighbourhood of the temple of Bel. The Palmyrene group who gathered in this building was probably composed by the elite members of the community, led by the sacerdos of $\mathrm{Bel}$, as P. Aelius Malachus was. It was supposed a strong link between these societies and the political power, mainly with the imperial cult. ${ }^{61}$ At Porolissum this connection is proved by the same P. Aelius Malachus' quality of flamen of the imperial cult in the municipium Porolissense and sacerdos of Bel at the same time. A religious complex as that at Porolissum, composed of temple, altar and banqueting hall is also known on the Eufrat River, South of Babylon. Here, at Vologesias, a strong community of Palmyrene merchants built a temple, a cultic altar and a banquet hall, as mentions an inscription at Palmyra from AD 108. ${ }^{62}$ In Dacia another possible banquet hall was found at Tibiscum, another military center with a Palmyrene garrison. Here a building of $28,80 \times 6,80 \mathrm{~m}$ was considered a schola used by the Palmyrene soldiers for dedicating monuments to the gods. ${ }^{63}$ The plan, the sizes of the building and the porticus from the entrance are similar with the banquet hall from Porolissum. But a very interesting and not yet approached subject is the topographical position of the Palmyrene complex at Porolissum. In Italy, the Palmyrene merchants had stations in Ostia, Puteoli and even in Rome. Vigna Bonelli in Rome where the inscriptions and other structures and artifacts related to oriental cults were found is situated on the western bank of the Tiber River, south of Porta Portese at the edge of Horti Caesaris; across the river after crossing Pons Sublicius it was the so-called "emporium", a commercial area with harbor, magazines, very important for trade. ${ }^{64}$ It is very probable that was the reason for the Palmyrene statio was placed in the vicinity, the economic interest of the Palmyrene community being the main reason. The epigraphic texts mentioned attest a mercantile association. Even at Porolissum the situation was different from Rome and Italy we are concerned about the vicinity of the Palmyrene complex with the customs building and with the commercium from the neighbourhood (Fig. 6-7). We think this position was not accidental. ${ }^{65}$ In the Roman East Palmyrene and Nabataean temples were often placed along the main trading routes ${ }^{66}$ At Porolissum, the same commercial interest determined them to build their "national" temple on the edge of the last segment of the main imperial road which crossed Dacia leaving the Empire at only few meters from the temple of Bel. At the same time, in the Roman Near Est and not only there very often the temples were erected in the very close neighbourhood of marketplaces and agoras. ${ }^{67}$ At Porolissum the main reason was, in our opinion, the economic interest

57 CIL VI, 52=ILS 4335.

58 KAIZER 2002, 220-229; 229-234; RAJA 2015, 191.

59 NIELSEN 2015.

${ }^{60}$ GNOLI 2016, 31-34.

${ }^{61}$ GNOLI 2016, 35.

62 TERPSTRA 2013, 160.

63 PISO/BENEA 1999, 104-106, Fig. 11.

64 TERPSTRA 2013, 152.

65 SMITH 2013, 155 for the relation between the location of the sanctuaries and the mercantile activities of the Palmyrenes.

66 See, GROUT 2016.

67 GROUT 2016, 182. 
of the Palmyrene merchants' community to stay in "pole position" towards the trading gate between the Empire and Barbaricum, being interested, among others, in the trade with amber and slaves, both merchandise available in the commercium. As a matter of fact, a fragmentary inscription dedicated to Dea Syria ${ }^{68}$ by Aur(elius) Gaianus dec(urio) m(unicipii) P(orolissensis) sace $(r) d o(s)$ was also recovered by the old excavation, without having the indication of the exact place of discovery, but very probable from the area of the temple of Bel. ${ }^{69}$ Aurelius Gaianus, as a sacerdos (of Dea Syria, or even of Bel?) was a civilian Palmyrene ${ }^{70}$ (or Syrian) with a high social position (decurio) in the municipium's administration, probably a merchant. Very interesting was F. Coarelli's approach explaining who were the people honouring Dea Syria in Rome. He started from the idea that Dea Syria ${ }^{71}$ was popular with the slaves and slave traders and the Palmyrene and Syrian cults in Rome are the result of slave trade. ${ }^{72}$ Even not decisive, the example of Aurelius Gaianus (possible a slaves' trader?) and the finds from the marketplace at Porolissum, represent a supporting evidence for Coarelli's hypothesis. In the ancient village of Baetocaece, in the territory of Arados it is recorded a trading fair. The nature of this fair is indicated by a Greek inscription: "slaves, cattle and other animals"73, a very important place for the Roman slaves' trade, Syria being one of the great suppliers. ${ }^{74}$ The same goods were also traded in the commercium at Porolissum, which was also an important fair on the northern frontier. The position of the Palmyrene community in the Porolissum's territory having a monumental religious complex of buildings just a few meters across the customs station and the limes wall (Fig. 8) sent a strong propagandistic message to the economic competitors that the trade is an assigned field by a strong and closed ethnic group ${ }^{75}$, with its own god, their leaders being members of local political elite and having behind an auxiliary ethnic military unit. The strong political position of the Palmyrene group is obvious in the inscription mentioning the rebuilding of the temple of $\mathrm{Bel}$, dedicated to the emperor Caracalla by numerus Palmyrenorum Porolissensium with mentioning of the governor of the three Dacias and of the procurator of Dacia Porolissensis, a demonstration of their loyalty to the emperor. The architectural oriental elements of the temple, reminding the big temple from Palmyra, the spectacular attire of the sacerdotes and their exclusivist meetings and religious rituals must have been impressive for the people at Porolissum, The Palmyrene merchants' community at Porolissum was obviously part of the trading network of this commercial oriental diaspora spread everywhere in the provinces of the Empire, from Palmyra till Rome. ${ }^{76}$ The very presence of the Palmyrene merchants in the commercium is not easy to demonstrate by material evidence. However, there is a rare artifact among the more than 1000 small finds recovered in the area of the commercium that worth to be mentioned. It is a bronze rotary key with ring. The characteristic which makes it special is the inscription perforated in the bit of the key: TYXH (Fig. 9). Keys with inscriptions of this type are very rare. A close analogy exists in the British Museum with the inscription $Y \Gamma I A .{ }^{77}$ The artifact was not a merchandise, there was not any building in the area, so it was used to secure a box. It was a Roman merchant carrying with him a box for some valuable goods. The key was probably kept secured hanged at the neck. That means the inscription has also an apotropaic function, TYXH being chosen intentionally

68 DAICOVICIU 1937-1940, 352, nr. 6; GUDEA 1989, 768, nr. 37.

69 DIACONESCU 2011, 142.

70 ARDEVAN 1998, 187-188; 566 (Tab. XXVI).

${ }^{71}$ For Dea Syria in ancient sources see, DIRVEN 1997.

72 COARELLI 1982, 50-52; COARELLI 1984, 470-471. TERPSTRA 2016, 43 rejected Coarelli's hypothesis.

73 GROUT 2016, 185.

74 DIGNAS 2002, 162-163.

75 For the Palmyrene trading network based on ethnicity, see SELAND 2013, 381.

76 TERPSTRA 2016, 46, Fig. 2.

77 PACE 2014, 53, Fig. 7. 
by the owner who probably order the box and the key in a specialized workshop. It was very probable an imported item. Tyche is well known in classical Greek religion. But she was venerated also in Palmyra. Gad, or Tyche was presented there as the protector divinity of the city. On a fresco from the temple of Bel at Dura-Europos, dated AD 239, Iulius Terentius, the tribune of cohors XX Palmyrenorum is depicted sacrificing to three armed gods; under the images of the gods the protective goddesses of Palmyra and Dura are presented seating, with the inscriptions

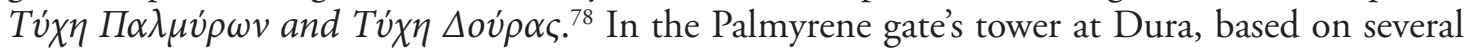
graffiti it was supposed even to exist a Tychaeum. ${ }^{79}$ The owner who lost the key with inscription TYXH in the commercium at Porolissum was very probable a merchant of Oriental origin speaking Greek language and borne in a region of Hellenistic culture, maybe a member of the Palmyrene community.

\section{REFERENCES}

\section{ALFÖLDI 1971}

G. ALFÖLDI, Bellum desertorum. Bonner Jahrbücher 171 (1971), 367-37.

ANDRADE forthcoming

N. ANDRADE, Palmyrene Military Expatriation and its Religious Transfer at Roman

Dura-Europos, Dacia and Numidia, forthcoming.

ARDEVAN 1998

R. ARDEVAN, Viața municipală ân Dacia romană (Timișoara 1998).

BAIRD 2011

J. A. BAIRD, The Graffiti of Dura-Europos. A Contextual Approach. In: J. A. Baird, C. Taylor (Eds.), Ancient Graffiti in Context (New York-London 2011), 49-69.

CASSOLA 1970

F. CASSOLA, I rapporti fra romani e buri in Cassio Dione. In: L. de Rosa (a cura di), Ricerche storiche ed economiche in memoria di Corrado Barbagallo I (Napoli 1970), 495-501.

CHIRILĂ ET ALII 1980

E. CHIRILĂ, N. GUDEA, AL. V. MATEI, V, LUCĂCEL, Raport preliminar asupra cercetărilor de la Moigrad (Porolissum) din anii 1977-1979. Acta Musei Porolissensis IV (1980), 81-101.

\section{COARELLI 1982}

F. COARELLI, I monumenti dei culti orientali a Roma. Questioni topografiche e cronologiche. In: U. Bianchi, M. J. Vermaseren (Eds.), La soteriologia dei culti orientali nell'impero romano (Leiden 1982), 36-67.

\section{COARELLI 1984}

F. COARELLI, Iside Capitolina, Clodio e i mercanti di schiavi. In: N. Bonacasa, A. Di Vite (Eds.), Alessandria e il mondo elenistico-romano: studi in onore di Achille Adriani (Roma 1984), 461-475.

\section{DAICOVICIU 1937-1940}

C. DAICOVICIU, Neue Mitteilungen aus Dazien. Dacia 7-8 (1941), 299-336.

\footnotetext{
78 KAIZER 1998, 48.

79 DJIKSTRA 1995, 49; 55. On the graffiti see, BAIRD 2011.
} 


\section{DIACONESCU 2011}

AL. DIACONESCU, Temples of Ethnic Communities (Assembly Halls) in Roman Dacia. An architectural prospective. Acta Musei Napocensis 45-46/I (2008-2009) [2011], 135-192.

DIETZ 1994

K. DIETZ, Zum Ende des Markomannenkriege: die expeditio Germanica tertia. In: H. Friesinger, J. Tejral, A. Stuppner (Hrsg.), Marcomannenkriege: Ursachen und Wirkungen (Brno 1994), 7-15.

DIGNAS 2002

B. DIGNAS, Economy of the Sacred in the Hellenistic and Roman Asia Minor (Oxford 2002).

DIJKSTRA 1995

K. DIJKSTRA, Life and Loyalty. A Study in the Socio-Religious Culture of Syria and Mesopotamia in the Greco-Roman Period Based on Epigraphical Evidence (Leiden-New York-Köln 1995).

\section{DIRVEN 1997}

L. DIRVEN, The Author of Dea Syria and His Cultural Heritage. Numen 44 (1997), 153-179.

FITZ 1962

J. FITZ, A Military History of Pannonia from the Marcomann Wars to the Death of Alexander Severus. Acta Archaeologica Academiae Scientiarum Hungaricae 14 (1962), 25-112.

\section{GAWLIKOWSKI 2015}

M. GAWLIKOWSKI, Bel of Palmyra. In: M. Blömer, A. Lichtenberger, R. Raja (Eds.), Religious Identities in the Levant from Alexander to Muhammed. Continuity and Change (Turnhout 2015), 247-254.

GNOLI 2016

T. GNOLI, Banqueting in Honour of the Gods. Notes on the marzéah of Palmyra. In: E. Kropp, R. Raja (Eds.), The World of Palmyra (Copenhague 2016), 31-41.

GRASSI 2010

G. F. GRASSI, Semitic Onomastics in Roman Aquileia. In: F. M. Fales, G. F. Grassi, CAMSEMUD 2007. Proceedings of the $13^{\text {th }}$ Italian Meeting on Afro-Asiatic Linguistics (Padova 2010), 1-31.

\section{GROH/SEDLMAYER 2019}

S. GROH, H. SEDLMAYER, Via publica vel militaris: Die Bernsteinstrasse in spätantoninischer und severischer Zeit. In: A. Kolb (Hrsg.), Roman Roads. New Evidence-New Perspectives (Berlin-Boston 2019), 191-214.

GROUT 2016

J. B. GROUT, The Role of Palmyrene Temples in Long-Distance Trade in the Roman Near East (London 2016, PhD Thesis)

\section{GUDEA 1989}

N. GUDEA, Porolissum. Un complex arheologic daco-roman la marginea de nord a Imperiului Roman, (Zalău 1989).

GUDEA 1994

N. GUDEA, Dacia Porolissensis în timpul războaielor marcomanice. Acta Musei Porolissensis 18 (1994), 67-91. 


\section{GUDEA 1996}

N. GUDEA, Porolissum. Un complex daco-roman la marginea de nord a Imperiului Roman. II Vama romană. Monografie arheologică. Contribuții la cunoașterea sistemului vamal din provinciile dacice, (Cluj-Napoca 1996).

\section{GUDEA ET ALII 1983}

N. GUDEA, E. CHIRILĂ, AL. V. MATEI, I. BAJUSZ, Raport preliminar în legătură cu săpăturile arheologice executate la Moigrad (Porolissum) în anii 1980-1982. Acata Musei Porolissensis VII (1983), 119-148.

\section{KAIZER 1998}

T. KAIZER, De Dea Syria et aliis diis deabusque. A Sudy of the Variety of Appearence of Gad in Aramaic Inscriptions from the Near East in the First three Centuries AD. (Part 2). Orientalia Lovaniensia Periodica 29 (1998), 33-62.

\section{KAIZER 2002}

T. KAIZER, The Religious Life of Palmyra: A Study of the Social Patterns of Worship in the Roman Period (Stuttgart 2002).

\section{KIENAST/ECK/HEIL 2017}

D. KIENAST, W. ECK, M. HEIL, Römische Kaisertabelle. Gründzuge einer römischen Kaiserchronologie (Darmstadt 2017).

\section{KOLENDO 2000}

J. KOLENDO, Eksport niewolników pochodzących z Europy barbarzyńskiej na teren Cesartswa Rzymskiego. Swiatowit NS 43.2 (2000), 112-127.

\section{KOVÁCS 2008}

P. KOVÁCS, Burgus Building Inscriptions of Commodus from Pannonia. Sylloge Epigraphica Barcinonensis VI (2008), 125-138.

\section{MOATTI 2011}

C. MOATTI, La mobilite negociee dans l'Empire romain tardif: le cas des marchands etrangers. In: Le relazioni internazionali nell'alto medioevo. Settimane di studio della Fondazione Centro italiano di studi sull'alto Medioevo, 58, Spoleto, 8-12 aprile 2010 (Spolete 2011), 159-188.

\section{MOATTI 2017}

C. MOATTI, Migration et droit dans l'Empire Romain. Catégories, comtrôles, et integration. In: E. Lo Cascio, L. E. Tacoma (Eds.), The Impact of Mobility and Migration in the Roman Empire. Proceedings of the twelfth Workshop of the International Network Impact of Empire (Rome, June 17-19, 2015) (Leiden-Boston 2017), 222-245.

\section{MONFERRER-SALA 2013}

J. P. MONFERRER-SALA, A King Amongst Kings. On the Term $m l k$ in the Context of the North-Arabian Aramaic Inscriptions. In: J. P. Monferrer-Sala, W. G. E. Watson (eds.), Archaism and Innovation in the Semitic Languages (Córdoba 2013), 93-112.

\section{NEMETI 2016}

S. NEMETI, Despre expeditio Burica și prezența detașamentelor legiunii III Italica în Dacia. Acta Musei Porolissensis XXXVIII (2016), 281-287.

\section{NIELSEN 2015}

I. NIELSEN, The Assembly Rooms of Religious Groups in the Hellenistic and Roman Near 
East: a Comparative Study. In: M. Blömer, A. Lichtenberger, R. Raja (Eds.), Religious Identities in the Levant from Alexander to Muhammed. Continuity and Change (Turnhout 2015), 47-74.

OPREANU/LĂZĂRESCU 2015

C. H. OPREANU, V.-A. LĂZĂRESCU, A Roman Frontier Marketplace at Porolissum in the Light of Numismatic Evidence. Contribution to the Roman Limes Economy (Cluj-NapocaZalău 2015).

\section{OPREANU/LĂZĂRESCU 2019}

C. H. OPREANU, V.-A. LĂZĂRESCU, The Basilica of the Forum at Municipium Septimium Porolissense (Dacia). An Overview. In: Visy 75 Artificem commendat opus. Studia in honorem Zsolt Visy (Pécs 2019), 397-410.

\section{OPREANU/COCIȘ/LĂZĂRESCU 2020}

C. H. OPREANU, S. COCIȘ, V.-A. LĂZĂRESCU, Barbarian Brooches in Roman Context. Analysis of the Finds from the Frontier Marketplace at Porolissum (Romania). In: A. Rubel, H. U. Voss (Eds.), Experiencing the Frontier and the Frontier of Experience (Oxford 2020), 67-93.

PACE 2014

T. D. PACE, A Typology of Roman Locks and Keys (PhD Thesis 2014)

PISO 2013

I. PISO, Fasti Provinciae Daciae II. Die riterlichen Amtsträger (Bonn 2013).

PISO 2018

I. PISO 2018, Das verhängnisvolle Jahr 262 und die amissio Daciae. In: L. Vagalinski, M. Raycheva, D. Boteva, N. Sharankov (Eds.), Proceedings of the First International Roman and Late Roman Thrace Conference "Cities, Territories and Identities" (Plovdiv $3^{\text {rd }}-7^{\text {th }}$ October 2016) (Sofia 2018), 427-440.

PISO/BENEA 1999

I. PISO, D. BENEA, Epigraphica Tibiscensia. Acta Musei Napocensis 36/I (1999), 91-107.

PISO/OPREANU/DEAC 2016

I. PISO, C. H. OPREANU, D. DEAC, Das Heiligtum der Zollstation von Porolissum. Zeitschrift für Papyrology und Epigraphik 200 (2016), 544-549.

POULTER 2014

A. POULTER, Illyricum and Thrace from Valentinian I to Theodosius II. The Radical Transformation of the Danubian Provinces. In: I. Jacobs (Ed.), Production and Prosperity in the Theodosian Period (Leuven-Walpole 2014), 27-68.

RAJA 2015

R. RAJA, Cultic Dining and Religious Pattern in Plamyra. The Case of the Palmyrene Banqueting Tesserae. In: S. Faust, M. Seifert, L. Ziemer (Hrsg.), Antike. Architektur. Geschichte. Festschrift fur Inge Nielsen zum 65. Geburtstag (Aachen 2015), 181-199.

SALDERN 2003

F. v. SALDERN, Studien zur Politik des Commodus (Rahden/Westf. 2003).

ŠAŠEL KOS 1996

M. ŠAŠEL KOS, The Defensive Policy of Valentinian I in Pannonia-A Reminiscence of Marcus 
Aurelius. In: R. Bratož (Hrsg.), Westillyricum und Nordostitalien in der spätrömischen Zeit (Ljubljana 1996), 145-175.

SELAND 2013

E. H. SELAND, Networks and Social Cohesion in Indian Ocean Trade: Geography, Ethnicity, Religion. Journal of Global History 8.3 (2013), 373-390.

SMITH 2013

A. M. SMITH II, Palmyra. Identity, Community \& State Formation (Oxford 2013).

STOKLAS 2019

B. STOKLAS, Der Einfluss der Markomannenkriege auf die Zirkulation der römischen Münzen im Mitteldonaugebiet in der 2. Hälfte des 2. Jahrhunderts-aktuelle Forschungen. In: M. Karkowski, B. Komoróczy, P. Trebsche (Hrsg.), Auf der Spuren der Barbaren-archäologisch, historisch, numismatisch (Archäologie der Barbaren 2015) (Brno 2019), 185-194.

TAMBA 2008

D. TAMBA, Un complex daco-roman la marginea de nord a Imperiului Roman 4. Așezarea civilă (vicusul militar) a castrului mare de la Porolissum (Cluj-Napoca 2008).

\section{TEICHNER 2013}

F. TEICHNER, From Aquileea to Carnuntum: geographical Mobility along the Amber Road. Veleia 30 (2013), 47-73.

\section{TERPSTRA 2013}

T.T. TERPSTRA, Trading Communities in the Roman World: A Micro-Economic and Institutional Perspective (Leiden-Boston 2013).

TERPSTRA 2016

T. T. TERPSTRA, The Palmyrene Temple in Rome and Palmyra's Trade with the West. In: J.C. Meyer, E. H. Seland, N. Anfinset (Eds.), Palmyrena: City, Hinterland and Caravan Trade Between Orient and Occident. Proceedings of the Conference Held in Athens, December 1-3, 2012 (Oxford 2016), 39-48.

T,ENTEA 2012

O. T,ENTEA, Ex Oriente ad Danubium. The Syrian Units of the Danube Frontier of the Roman Empire (Cluj-Napoca 2012).

\section{VAN'T DACK 1991}

E. VAN'T DACK, Commode et ses épithètes Pius Felix sous les Sévères. In: G. Bonamente, N. Duval (Eds.), Historiae Augustae Colloquium Parisinum. Atti dei Convegni sull Historia Augusta I (Macerata 1991), 311-335. 


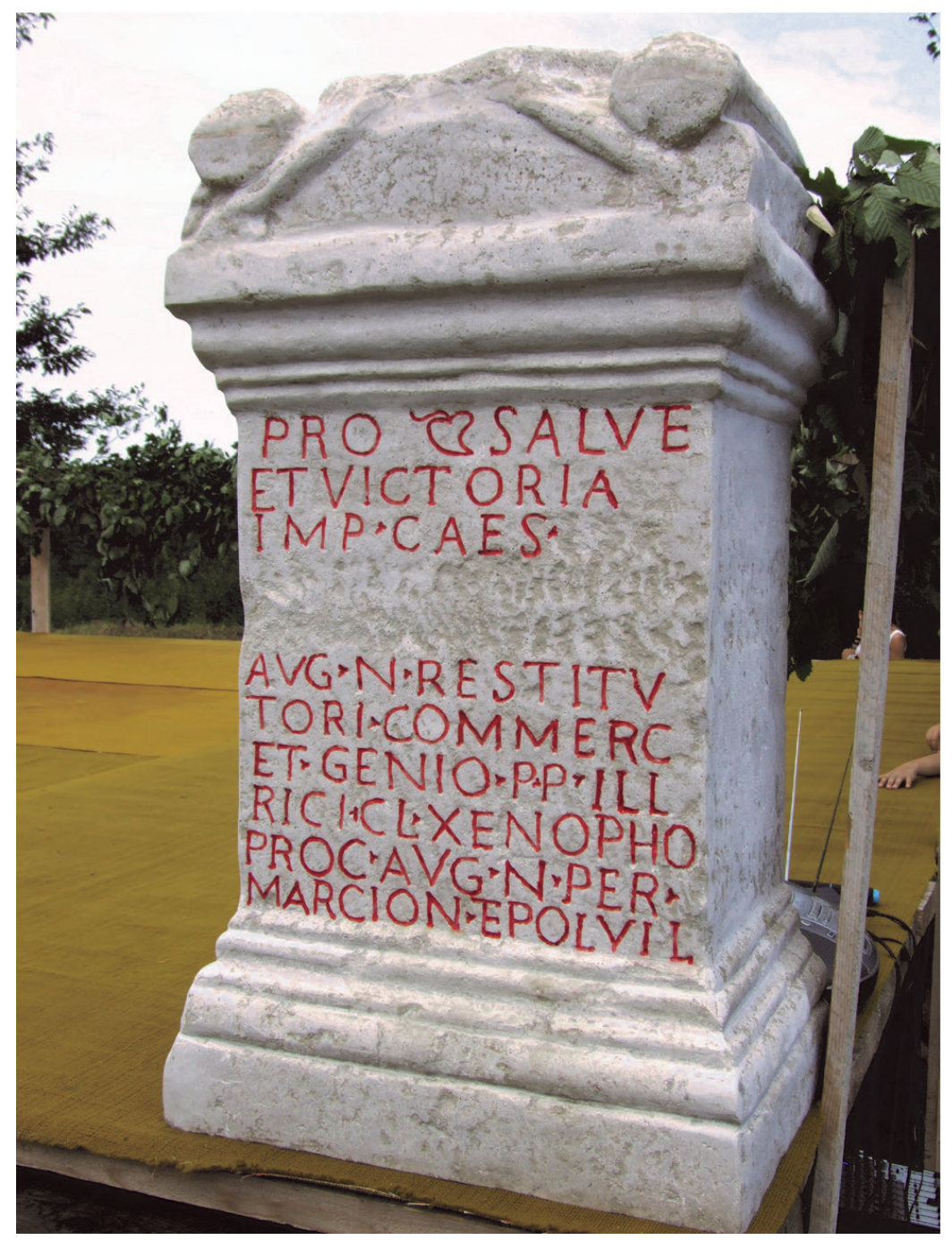

Fig. 1 - Inscription of Commodus from the shrine of the customs building at Porolissum (replica in situ made by the Sălaj County's Museum from Zalău). 


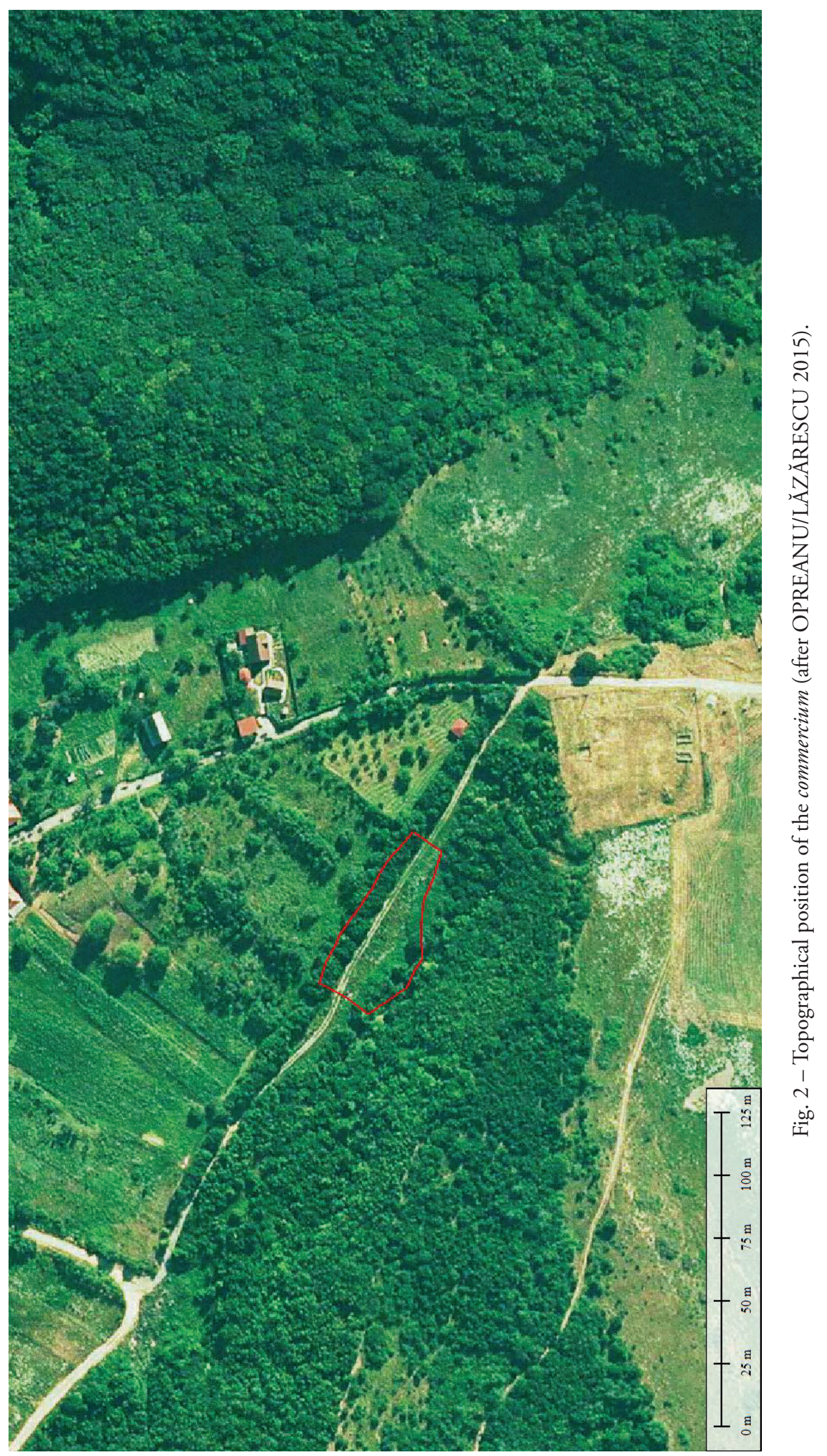




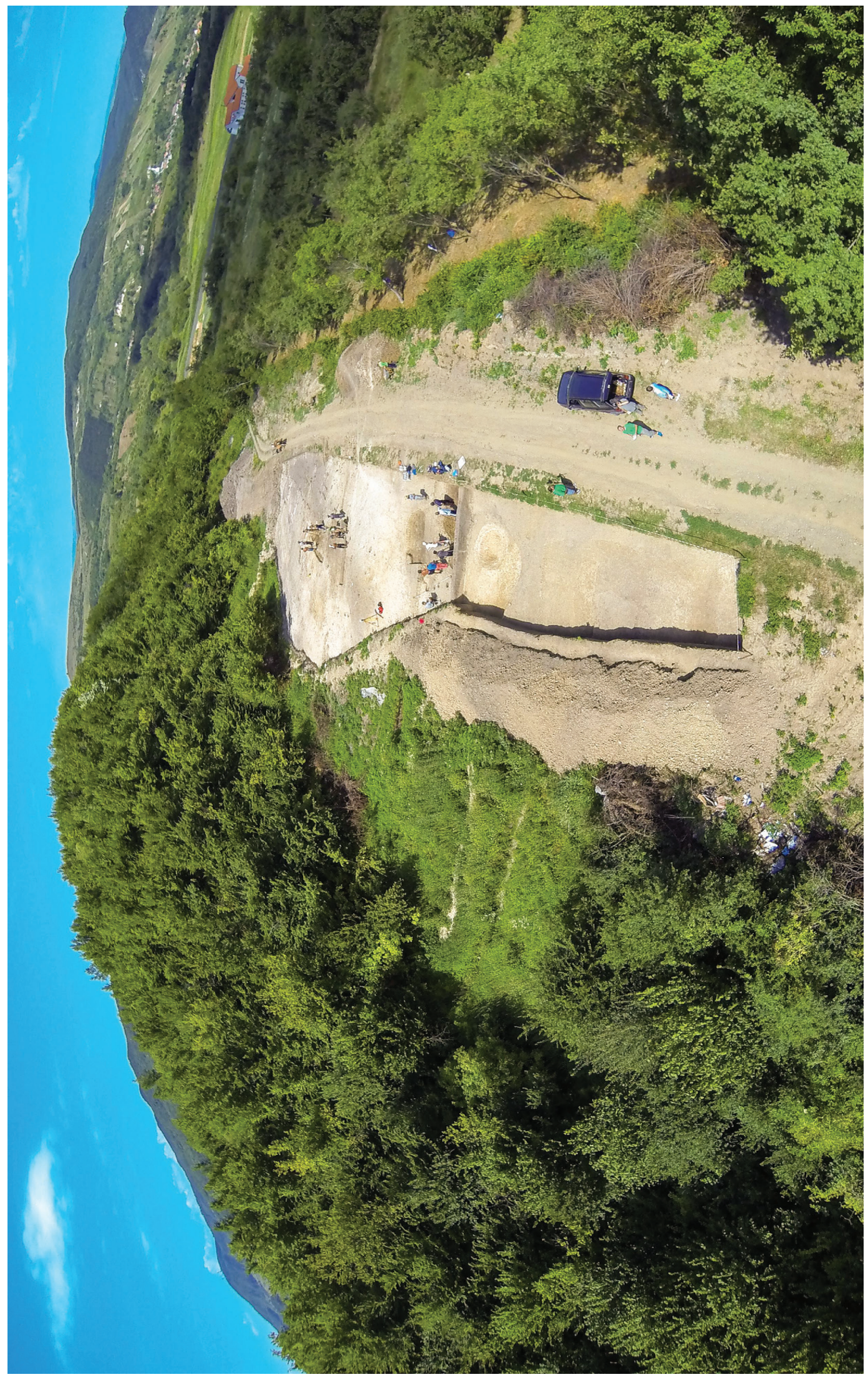




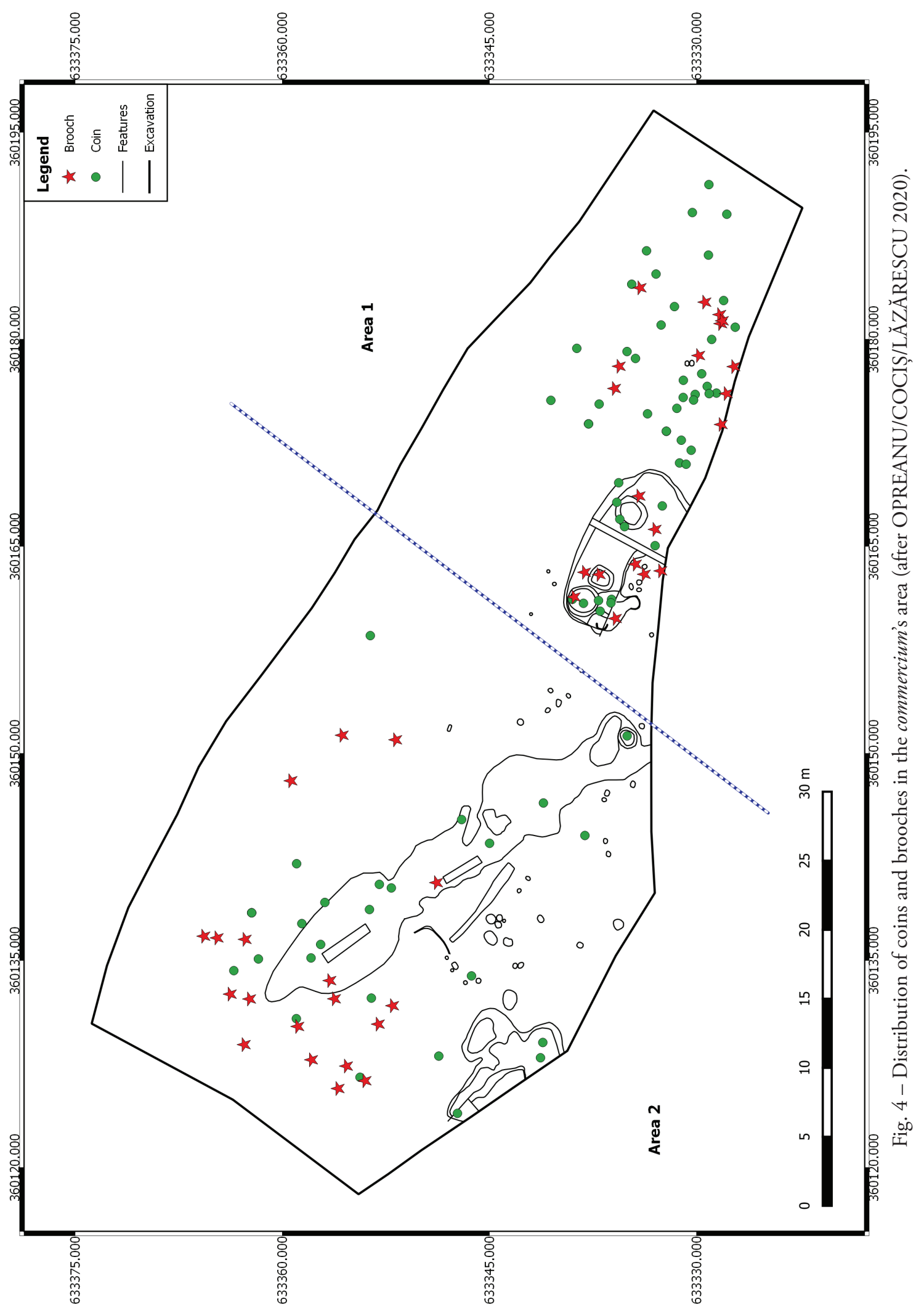




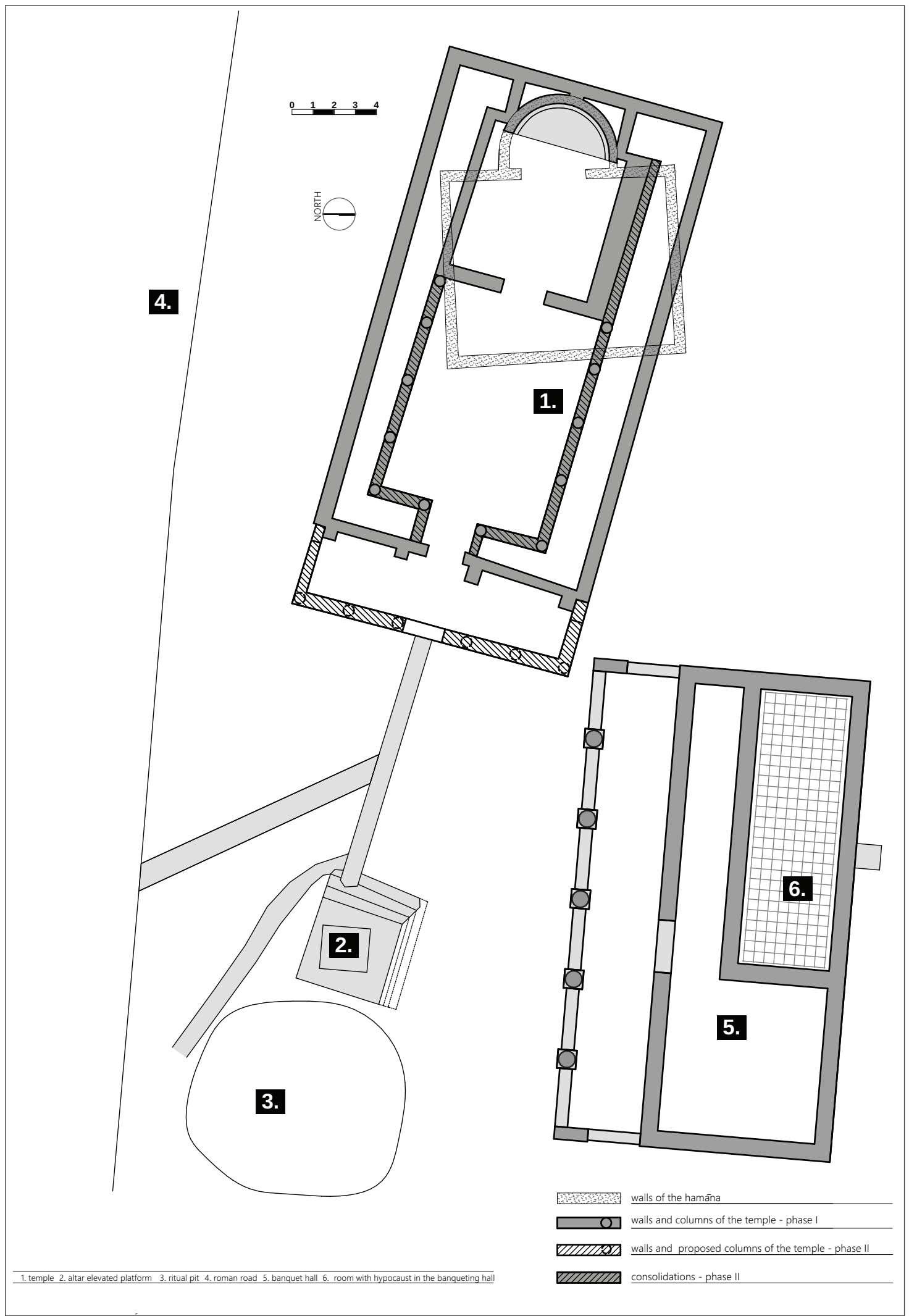

Fig. 5 - Plan of the Palmyrene cult complex at Porolissum (author, architect FLAMINIU TALOȘ) 


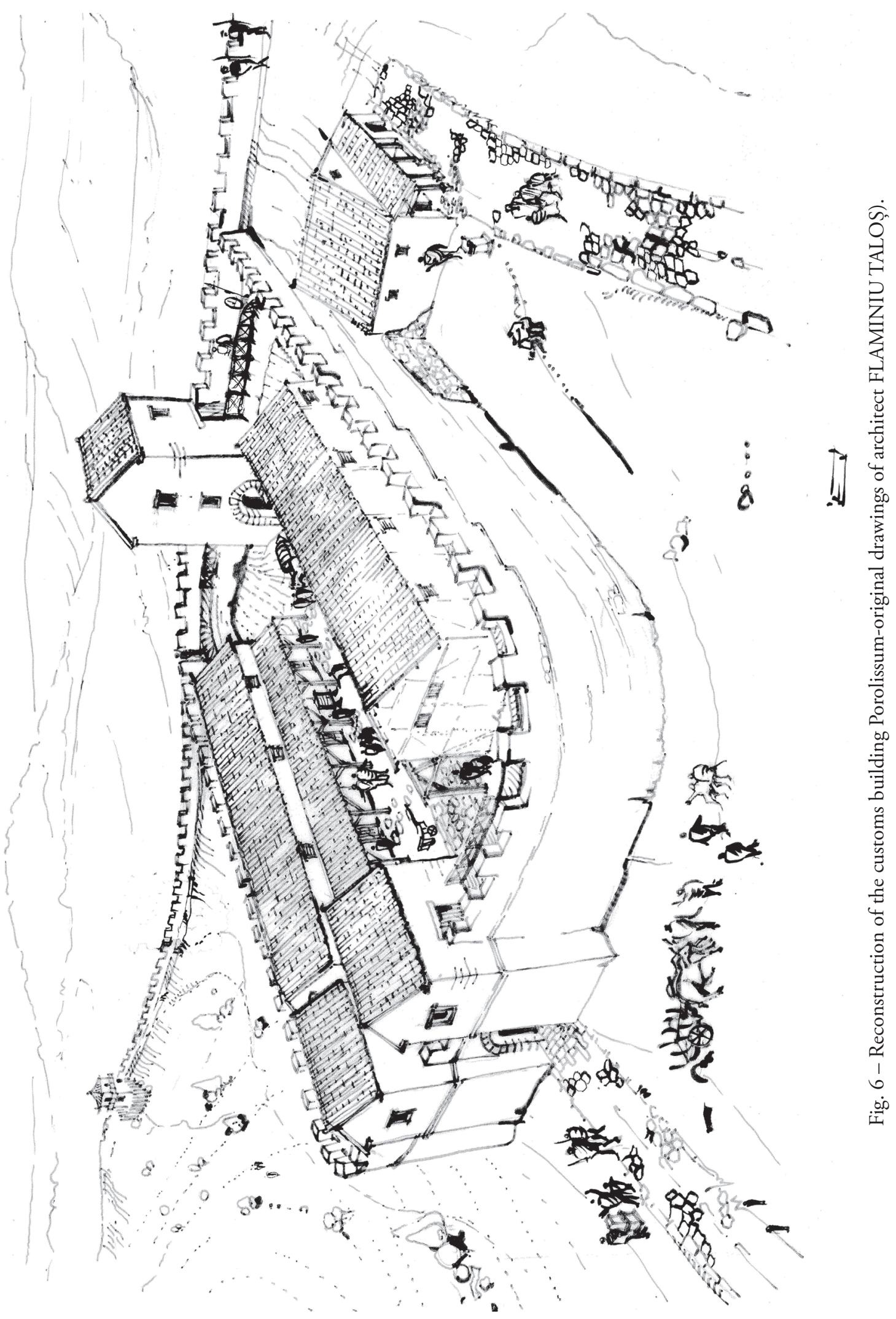




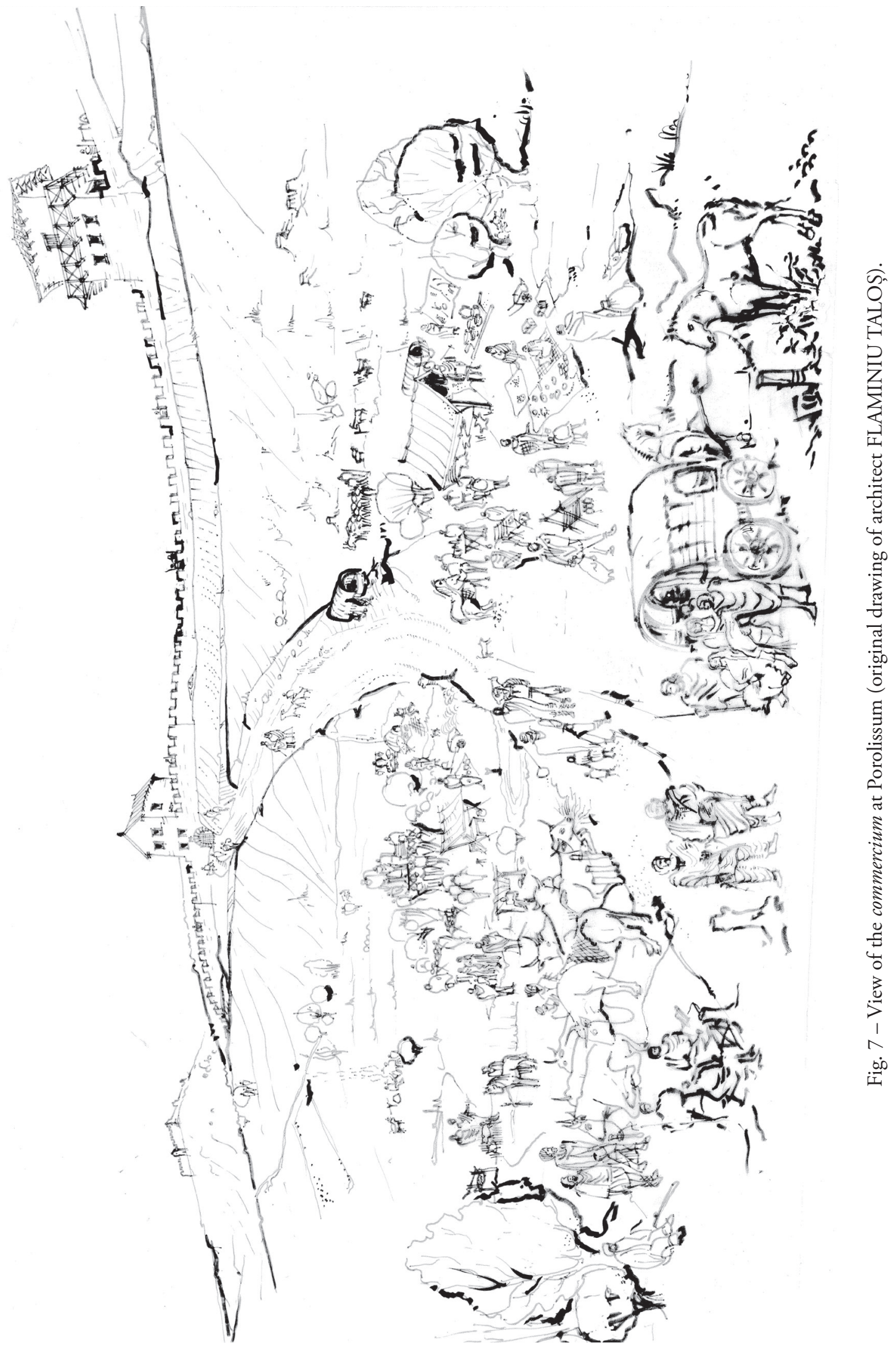




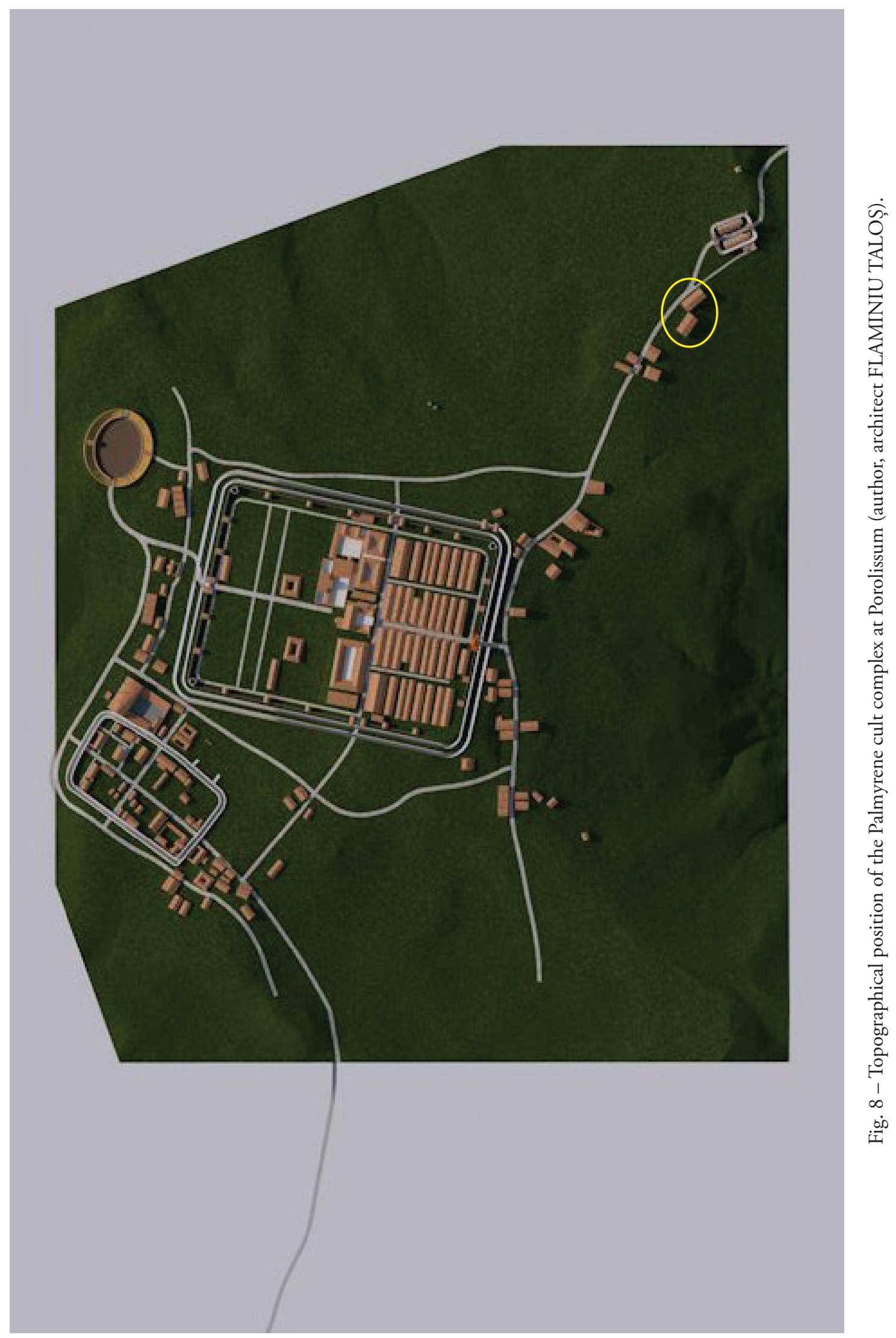




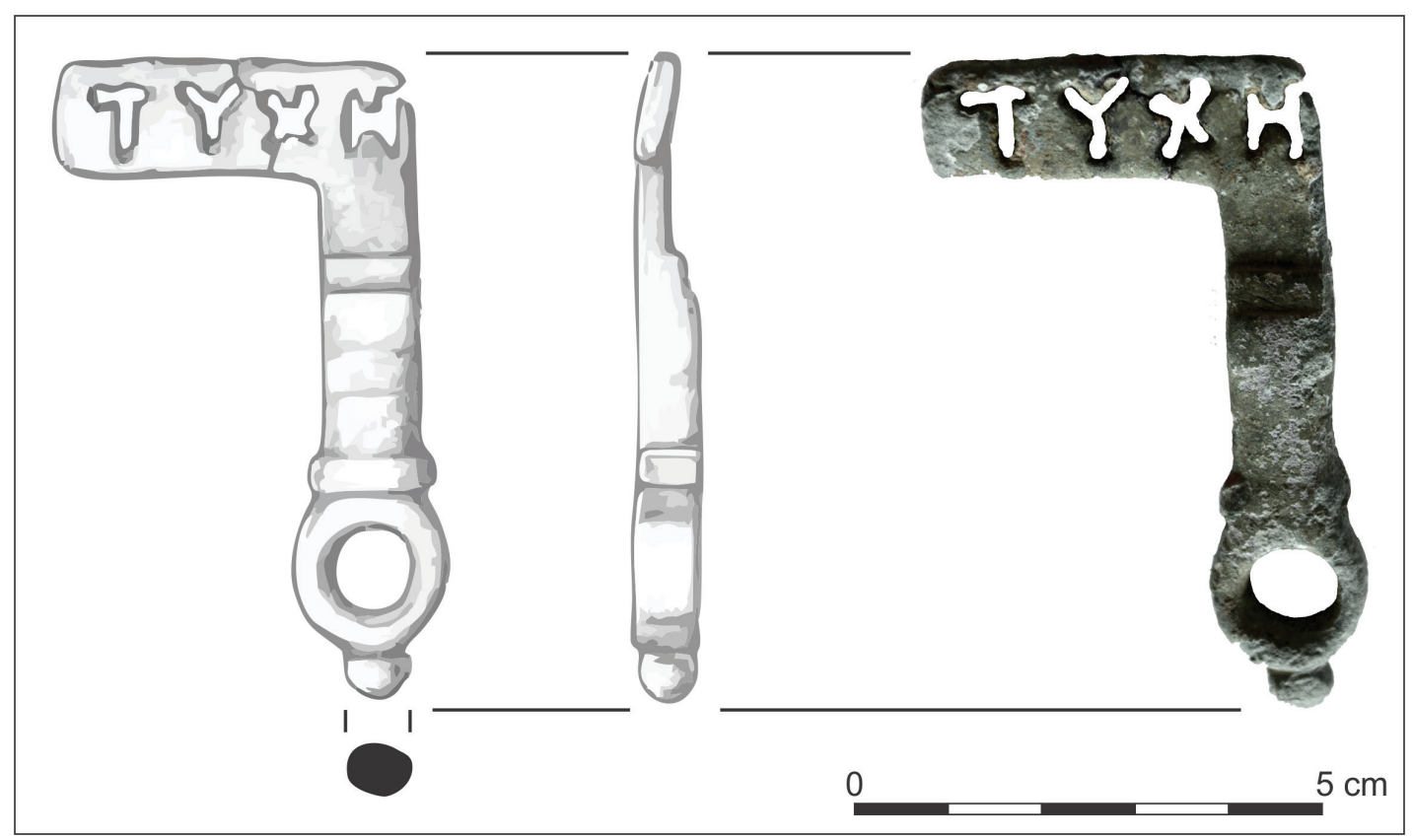

Fig. 9 - Bronze key with perforated inscription in the bit found in the commercium area. 